\title{
Jesus and cultural values: Family life as an example
}

\author{
Carolyn Osiek \\ Department of Biblical Literature \\ Catholic Theological Union, Chicago, USA
}

Visiting Professor: Department of New Testament Studies (Sec A)

University of Pretoria

\begin{abstract}
'Family values' is a set of traditional images that most cultures collect, images drawn mostly from an idealized picture of family life in the recent past. For Christians, the popular image of Jesus gets included: the Holy Family as a nuclear family unit, Jesus blessing children, Jesus as advocate of traditional family life. A closer reading of both contemporary family life and the Gospels reveals that things are not what they seem. Contemporary family life in Western societies is structured quite differently than the ideal. Jesus' family life was spent in a peasant village surrounded by relatives and neighbors, with little privacy and strong social pressure towards conformity. The gospel records indicate that he did not conform, and paid the price: rejection and misunderstanding by his extended family. The Synoptic Gospels consistently portray not only an estrangement between Jesus and his family, but Jesus' encouragement of his disciples to break family ties in favor of the surrogate family of the circle of disciples. In a culture in which kinship loyalty was essential, this message caused deep problems for early Christians which the authors of the household codes of Ephesians, Colossians, the Pastoral Epistles, and 1 Peter tried to alleviate.
\end{abstract}

Since I have not yet been to South Africal, I cannot with certainty describe the popular images of family life there. I suspect, however, that at least in white culture they are not that different from those in the United States: a close-knit nuclear family composed of working father, stay-at-home mother, happy children - at least one of either sex and a dog, a family unit that is in cordial but independent relationship with its extended

* Paper presented at the Images of Jesus Seminar, Research Institute for Theology and Religion, University of South Africa, September 3-4, 1997 
family. This ideal family abhors and does not engage in divorce, contraception, abortion, homosexuality, or extramarital sex. Among traditional African cultures, other factors may enter in, especially in the understanding of the nuclear family unit and its relationship to the rest of the family system, but research in America has found that the ideal described above is rather constant across cultures in the United States.

These basic characteristics form the core of what Americans like to call 'family values'. Historical research has further shown that these ideals have been consistently created about life in the recent past, that is, each generation retrojects the same ideals onto a generation recently past. Currently in the United States, it is the generation of the 1950's that bears the image. A popular television show called 'Leave it to Beaver' that exemplifies this, is still shown on late-night reruns. In keeping with these images, there are certain popular biblically based images of Jesus with regard to family life. Among them priority is given to Luke's two statements about Jesus' childhood in Nazareth: after the two visits to the Temple, Jesus went with his parents to Nazareth where he grew in grace and was subject to them ( $L k 2: 39-40,51)$. These simple lines form the basis of the idealization of the Holy Family as a nuclear unit. Other images include Jesus blessing the little children (Mt 19:13-15 [par Mk 10:13-16; Lk 18:15-17]) and setting before the disciples a child as an example of qualifications for entry into the kingdom (Mt 18:1-5 [par Mk 9:36-37; Lk 9:48; Gos Thom 22]). A close relationship between Jesus and his mother, drawn mostly from Luke 2:51 and John 19:26-27, completes the biblical image. The silence of the Gospels with regard to the life and death of Joseph is supplemented by early Christian piety, so that Jesus the devoted son worked with his father in his trade and was present with Mary when Joseph died contented $^{2}$. Afterwards, according to the tradition, the relationship between Jesus and his mother became even closer. This picture is certainly in keeping with Mediterranean family patterns, in which men married younger women who were thus widowed first, and in which one of the closest bonds is that between mother and son.

The other very close bond, however, is between brothers and sisters. Here the ties of mutual protectiveness and loyalty may be closer than those between husband and wife. But the brothers and sisters of Jesus, whether actual siblings or near relatives, were soon conveniently forgotten, replaced eventually by the nuclear family with its only child as image of the ideal family. This image of the triadic Holy Family did not emerge strongly until the nineteenth century in the West, but it is very interesting to ask why - given the usual close Mediterranean cultural bonding between brothers and sisters - there are not stronger early traditions about such family patterns around Jesus. 
A closer reading of our contemporary family life today reveals quite a different picture than the idealized one, as families and households struggle to survive amidst complex social and economic pressures. In the United States, for instance, about 25 per cent of households now consist of the traditional composition of father, mother, and children of them both, and of that 25 per cent, half again have both parents in the labor force.

Likewise, a closer reading of the Gospels indicates something different: a seeming hostility between Jesus and his family, and a constant challenge in Jesus' preaching away from loyalty to family. But before exploring Jesus' attitude toward family life, we must deal with two preliminary questions.

The first question is, how reliable are the Gospels to tell us about events and even attitudes of the historical Jesus? This is a perennial question that must be raised, but cannot be dealt with here. I can simply state my own presuppositions, which lie in a moderate direction: that the Gospels represent authentic traditions about Jesus and therefore are essentially reliable with regard to general direction, though specific stories, characters, and interpretations may well be the product of later tradition or of the evangelists. For our purposes, I would maintain that the Synoptic Gospels preserve authentic, albeit problematic, memories of Jesus and his relationship to his family. However, it must be kept in mind that we have access only to the portraits of Jesus provided by the evangelists, not to the historical Jesus himself.

The second preliminary question is, what did Jesus know as family life? To begin, we must acknowledge that even the terminology does not match a modern view. The

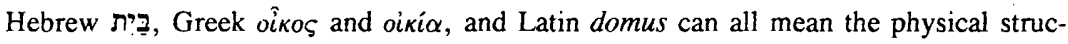
ture of the house, but more often the household as a horisontal social concept, including those related by blood - who may or may not be living under the same roof and slaves, freemen/women, and material goods of the house. Consider the following three different uses of 'house' (oíkоৎ) in 1 Corinthians. Paul baptises the oikos of Stephanas (1 Cor 1:16), meaning the persons of the household. Aquila and Prisca hold an $\dot{\varepsilon} \kappa \kappa \lambda \eta \sigma i \alpha$ in their oikos (1 Cor 16:19), meaning both the physical space and its inhabitants. Women are told to bring their questions not to the $\dot{\varepsilon} \kappa \kappa \lambda \eta \sigma i \alpha$ but to their husbands $\dot{\varepsilon} v$ oik $\varphi$ (1 Cor 14:35), meaning the social construct of private space, which was apparently conceptually different from the oikos in which Aquila and Prisca were holding their meetings.

To confuse the issue further, Latin has another word, familia, meaning all those under the authority of the paterfamilias, the male head of the household. The referents in this term could be several generations of descent living in many different locales, and in many situations did not include the wife of the paterfamilias, mother of those 
generations, because she may have been married sine manu, that is, remaining a member of her father's familia instead of moving into that of her husband. This was the more common form of Roman marriage by the first century CE (see Saller 1984:33655; 1994:74-101).

Jesus, of course, was not a Roman. But the same flexibility of terminology prevailed in both Hebrew and Aramaic and in Jewish conceptualisation. Jesus is of the

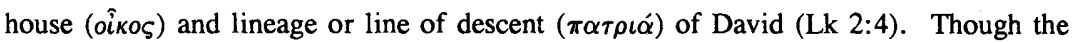
English word 'family' (I regret my ignorance of Afrikaans here) can also refer to line of descent and to extended kinship patterns, in none of the ancient biblical languages was there a word that clearly meant what Westerners generally mean by family in the first instance: the nuclear family unit. Those conversant with African cultures will no doubt find a closer affinity there with what I have described about the Hebrew, Greek, and Latin systems. The only conclusion to be drawn is that the nuclear family was seen only as part of a larger social unit. This is still true in many cultures today.

What Jesus knew as family life was the extended family living in close proximity, though not necessarily under the same roof, but sharing life on a very close basis. What the Gospel narratives do not say is what they take for granted: that family life, especially in a small village, is always lived in what we would consider crowded conditions and as close proximity as possible to blood and intermarried relatives. Ancient villages, like medieval ones, were built as compactly as possible, with houses built into one another. Where the terrain allowed, houses were built onto caves, which formed the back rooms, naturally air-conditioned and thus perfect for food processing and storage. Whatever the historical claims to the site of the Church of the Annunciation in Nazareth, the cave complex under it gives evidence of such habitation. The greater part of living - cooking, eating, crafting, even sleeping - happened outside during the long Mediterranean summer, and thus in view of everyone. This close living with a consanguineous and coterritorial group creates a great deal of social pressure to conform to traditional expectations. Deviance is not welcomed.

The Gospels all suggest, and Matthew is explicit, that Jesus, as he began his ministry, moved to Capernaum on the north side of the Lake of Galilee (Mt 4:13). The reputed 'house of Peter' at Capernaum, whether historically authentic or not, gives archaeological evidence with its surroundings of the kinds of domestic structures likely to have been commonplace in the first century: an open courtyard with entrance to the street, surrounded by simple one- and two-room buildings (cf Corbo 1969; Tzaferis 1983:198-204). An extended family would share this common open space, each nuclear unit having its own building for some privacy. Such scenes as Matthew 8:1416 and Mark 1:29-35 suggest that Jesus did not 'have his own apartment' in 
Capernaum, but moved in with Peter's family. In these scenes, Jesus seems at home in the house of Peter and Andrew, where he simply replicates in Capernaum the same pattern of domestic life he had known in Nazareth: most of life spent in close proximity with companions and their relatives under intense scrutiny and pressure to conform.

It is rather surprising that in the earlier traditions represented by the Synoptics, the relationship between Jesus and his family seems cool at best. The tone is set by Luke's story of the boy Jesus in the Temple, seemingly oblivious of his parents' concern (Lk $2: 41-51)$. His retort when asked what he thinks he is doing is not helpful. Of course, Luke tells the story not to show Jesus as an adolescent brat, but to illustrate that even at that early age, he was both precocious and conscious of his identity and destiny.

The earliest narrative of the encounter of the adult Jesus with his family is in Mark 3:21, and it is not a happy one. Mark states briefly that in the midst of Jesus' enormous popularity with the crowds, his relatives or those from his home village (oi $\left.\pi \alpha \rho^{\prime} \alpha \dot{v} \tau o \hat{v}\right)$ came to fulfil their familial responsibility by taking hold of him because they thought he was out of his mind ( $\dot{\varepsilon} \xi \dot{\varepsilon} \sigma \tau \eta)$. His bizarre behavior was shaming their village and they had to do something about it. A little later, his mother and brothers ${ }^{3}$ tried again. They sent word to him through the crowd that they were outside (Mk 3:31-35; and parallels, Synoptic and beyond), in contrast to the crowd 'on the inside', sitting around him 4 Family loyalty and hospitality would have suggested an immediate response from him: receiving and entertaining the folks from home was an expected priority. However, instead of rising to receive them, he ignores them, stating that the crowds listening to his teaching take that place in his life: "Whoever does the will of God is my brother and sister and mother.'

Look at the context in Mark's Gospel: first Jesus chooses the twelve 'to be with him' and represent him (Mk 3:13-19). His family tries to take him away because they think he is out of his mind (3:21); he condemns the Jerusalem scribes for saying he is diabolically possessed (3:22-27), after which he comments on the unforgivable sin against the Holy Spirit, interpreted here as mistaking the spirit of God in Jesus for an unclean spirit (3:28-30); and then Jesus' blood relatives come to see him and he shuns them in favor of the crowd of disciples (3:31-35).

Though some commentators deny connections in the sequence of passages here, it is generally acknowledged that Mark does frequently arrange material so that juxtaposed passages interact with and comment upon each other. If this is true here, the choosing of the twelve as Jesus' closest circle of friends stands in contrast to the next scene in which Jesus' relatives completely misunderstand him. Then both the relatives and the scribes come under criticism by Jesus for not recognising the spirit of God in him and are therefore guilty of the unforgivable sin. Finally, Jesus' blood relatives 
come to see him and are ignored in favor of those who listen to his teaching. The two scenes of the family coming to snatch him and his rejection of their claims in favor of discipleship frame the sayings on the sin against the Holy Spirit. At this point in the Synoptics, the family exit the stage and are never seen again, in spite of the fact that they are known to others later in the story (Mt 13:55-56 [par Mk 6:3; Lk 4:22; Jn 6:42]).

I think there are reasons in the early church for depicting Jesus' behavior like this, but we will take them up later. Here, let us simply look at the image of Jesus that is presented - someone who is not at all close to his family and who does not give them much attention. They show no understanding of what he is doing.

The story continues. Luke (11:27-28) and Thomas (Gos Thom 79) has Jesus brush off a compliment to his mother, the most honorable role possible for a woman, in favor of those who hear the word and keep it. The disciples are encouraged in their renunciation of houses, brothers, sisters, father, mother, children and fields (Mt 19:27-29 [par Mk 10:28-30; Lk 18:28-30]). Jesus warns of divisions and betrayal within the family for the sake of the Gospel (Mt 10:21; Mk 13:12). However, it is part of his mission to cause such divisions (Mt 10:34-36 [par Lk 12:51-53])! Whoever loves parents or children more than Jesus is not worthy of him (Mt 10:37 [par Lk 14:25-26; Gos Thom 55, 101]). One called to discipleship may not look back, even to bury a dead father, the final solemn duty of a son (Lk 9:61; Mt 8:21-22 [par Lk 9:59-60]).

In the Gospel of John, Jesus' relatives fare a little better, but not extremely so. They are present at the marriage at Cana with Jesus and his disciples (by implication in 2:12); whole families and larger units attended weddings together. There, according to some interpreters, Jesus publicly rebuffs maternal authority, though he eventually obeys his mother, the duty of any adult son (Jn 2:1-11). According to John, after the wedding the whole family group and the disciples of Jesus, moving as a unit, go to Capernaum for a while. This picture of Jesus' disciples as an extension of his family is very typical, and it foreshadows the shift in symbolic language and attitude that seems to have happened in the preaching of Jesus.

By chapter seven, however, the brothers of Jesus have turned against him. In 7:35 , they urge him to leave Galilee for Judea at the feast of Tabernacles, in order to gain a wider audience. This does not sound negative, yet John seems to intend it so, as a taunt or strategy to be rid of him, since he adds in verse 5: 'Even his brothers did not believe in him.' From the cross, Jesus confides his mother to his favorite disciple in a touching scene (19:25-27). The scene is no doubt intended to convey deep ecclesiological significance. At its most basic level, however, Jesus is doing what any oldest son of a widowed mother must do if he knows he is dying: he is delegating his 
responsibility for her care to someone else. It may be equally significant that he hands her over not to one of his brothers or another male relative, but to a disciple. This too could signify the estrangement that exists between Jesus and the rest of the family.

The two exceptions to this familial estrangement may be Jesus' mother and one of his brothers, James. In Luke, Mary is an early disciple who is strangely missing later, especially at the time of Jesus' death, but resurfaces in Acts 1:14. In John, she seems to remain constant in her support of her son's strange doings, for she appears both at the beginning and at the end of his ministry.

James 'the brother of the Lord' appears in the Gospels only as one of a trio of Jesus' brothers known by the locals (Mt 13:55 [par Mk 6:3]). In Acts and Paul's letters, he emerges as a leading figure in the Jerusalem church. It is most unlikely that he would have been accepted as such if he had not shown considerable faith in Jesus during his brother's lifetime.

I conclude that Jesus' noticeable coolness toward most of his family and their lack of enthusiasm for him has a historical basis. The two exceptions may be Mary and James. We will return to ask why this picture of the family of Jesus was acceptable and even gratifying to the first disciples.

Before doing that, let us consider other aspects of Jesus' attitude toward family life. Certainly he is not portrayed as anti-family in general. His use of the term 'father' for God has been problematic in the history of scholarship. The usage undoubtedly goes back to the historical Jesus, but is not the unique feature that it once was thought to be. It does seem, however, to have been a characteristic of his own spirituality that was passed on to his disciples. Contrary to what is often thought, the title is not all-pervasive in the Gospels. It occurs rarely in Mark, infrequently in Luke, and frequently only in Matthew and John. Only in John's Gospel is the title indicative of a particular and unique relationship between Jesus and God. In the context of paternal connotations in the culture, it is not so much a title of affection and intimacy as of respect and need to please, though affection is certainly not to be totally excluded. Even here, as Jesus seems to reinforce the patriarchal structure of society, local domestic authority is potentially undermined by Jesus when he refers all paternal authority to God (Mt 23:9).

Jesus upholds the requirements of the fourth commandment against Pharisees and scribes who would bypass it (Mt 15:3-6 [par Mk 7:10-12]) and considers this commandment one of the essentials for someone who thinks he can do more than the commandments require (Mt 19:19 [par Mk 19:19; Lk 18:20]).

He understands and uses in his teaching the situations of household and managerial slaves, members of their owners' families, who are both debtors and creditors in the story of the unmerciful slave (Mt 18: 23-25) and of slaves entrusted with responsibility in the absence of their master (Mt 24:45-51 [par Lk 12:41-46]). The parable of the 
talents or pounds is about domestic slaves entrusted with a peculium, that is, money to invest on their own (Mt 25:14-30 [par Lk 19:11-27]). He tells a story about sibling rivalry between sons who have differing ways of responding to their father's orders (Mt 21:28-31). Jesus himself has to fend off a similar situation of rivalry among his own disciples when two brothers, the sons of Zebedee, aided and abetted by their mother in Matthew's version (as is only proper for a mother to do for her sons), try to get the advantage over the others in eschatological strategy (Mt 20:20-28 [par Mk 10:35-45]).

Jesus also demonstrates great sensitivity to family situations in which he can alleviate suffering through healing. He is especially kind to distraught parents of sick children: the synagogue official with a dying daughter (Mt 9:18-26 [par Mk 5:21-43; Lk 8:40-56]); a royal official with a sick son (John 4:46-53); the persistent SyroPhoenician or Canaanite woman with a sick daughter, who sacrifices personal dignity to get what she needs for her child (Mt 15:21-28 [par Mk 7:24-30]); and the father of a possessed boy (Mt 17:14-20 [par Mk 9:14-28; Lk 9:37-42]). He is especially responsive to the plight of a widow at Nain whose only son has died (Lk 7:11-17), for he has pity on her and proceeds to raise her son without even being asked. It is a situation that may foreshadow that of his own mother, if the 'brothers and sisters' spoken of in the texts are not siblings but cousins and villagers.

Jesus is extremely sensitive to the familial relationships of others, shown especially in his response to distraught parents of sick or dying children. Why then is he portrayed with so little interest in his own family? I think there are two reasons. First, there is a historical basis for this portrait of mutual neglect. The extended family of Jesus did not on the whole support him, but found him an embarrassment, as did the whole village in which he was raised. His home visit to Nazareth after he had established a reputation as a healer is portrayed in all the Synoptics as a disaster (Mt 13:5358; Mk 4:12-17; Lk 4:16-30). The sole exception, other than Jesus' mother who may have stuck by him out of sheer maternal loyalty, 'was probably James. This alone may have earned him the nickname 'just' among Jesus' disciples.

The second reason for the portrayal of mutual coolness between Jesus and his family is the strong theme of displaced family values in discipleship. The circle of Jesus' disciples become his and their surrogate family. This is already announced in Mark 3:31-35 and parallels, where Jesus acclaims those who do God's will as mother, brother, and sister. Socially, as we have seen, the passage depicts outrageous behavior on Jesus' part by neglecting to respond immediately to his family's presence. Theologically, of course, the saying does not exclude his own family, but only removes their exclusive claim on him. The familial circle has been widened to include the disciples, who soon begin traipsing after him wherever he goes. All the sayings about 
leaving family are oriented in the same direction: the circle of disciples is now to perform the social function that family and home village have previously done, The first scenes of calling to discipleship all contain some element of leaving home or regular occupation: Simon and Andrew leave their nets; James and John leave their father and his work; Levi leaves his own employment (Mk 1:16-20; 2:13-14, and pars). The significance of James and John leaving their father is far greater than anything in the other narratives; this is what a son simply does not do. Obviously, these departures are not meant literally and completely, for Jesus is soon in the house of Simon and Andrew, already with his other two new disciples, James and John, accompanying him (Mk 1:29-31). The transitions are symbolic of what discipleship entails.

The pattern of breaking with family ties and customary roles continues through the narratives of discipleship in the Gospels. The sayings on discipleship reinforce renouncement not of possessions only but also of family. Disciples like Mary Magdalene, Joanna, and Susanna (Lk 8:2-3) are surely neglecting their traditional domestic roles, if they have not left them altogether. Like the male disciples, many of them continue with Jesus to Jerusalem. Never does Jesus express any misgivings about encouraging this abandonment of domestic and local responsibility on the part of his disciples. Even without his controversial teachings and prophetic actions, this alone would have sufficed to raise deep resentments against him.

In a peasant culture heavily invested in agriculture, with village life as the social and economic foundation and majority experience of its inhabitants, whence comes this idea that it is possible to walk out on one's responsibilities to contribute to the family's need to support itself, secure its property, and produce the next generation in order to perpetuate itself? This theme must be seen within the tradition of higher loyalty to philosophy, the state, or the law, as envisioned in a variety of ways in ancient literature. Deuteronomy 13:6-11 already warns Israel against letting family ties seduce into pagan worship. Philo, Josephus, and the Qumran writers all echoed the same concern. For the author of 4 Maccabees:

The law prevails even over affection for parents, so that virtue is not abandoned for their sakes. It is superior to love for one's wife, so that one rebukes her when she breaks the law. It takes precedence over love for children, so that one punishes them for misdeeds. It is sovereign over the relationship of friends, so that one rebukes friends when they act wickedly. 
The same writer later extols the seven martyred brothers for resisting the 'bewitching power' of brotherly love because they could withstand the urge to submit when watching their brothers being tortured to death (4 Macc 13:19-27). In the thinking of the first followers of Jesus, it is just one easy step from allegiance to the Law to allegiance to the absolute demands of discipleship.

In the Graeco-Roman context, the same absolute allegiance was expected from Cynics, Stoics, and others in the pursuit of philosophy. Epictetus, for example, advises that the Good is to be preferred to every demand of kinship, even the demands of father and brother (3.3.5-10).

Dionysius of Halicarnassus tells a Roman story in which intermarried Romans and Sabines must forsake their marital bonds when the two nations go to war against each other. A Roman girl engaged to marry a Sabine man mourns his death and then is killed by her brother for treachery against Rome. This story could also be seen to reinforce loyalty to family of origin over marital family, a typical kinship posture, and what it says about expectations of loyalty in marital bonds is very revealing. Yet the purpose of the story is to illustrate that loyalty to the state comes before any other kind 5 .

We see then that the motif of deprioritising family in favor of prioritising new allegiances with absolute claims to loyalty fits within a certain known context in the ancient Mediterranean world. This value system was glorified by writers who shared that worldview, that is, by those who agreed with the shifted loyalties and lived by them. To the general populace, such a value system must have been abhorrent, even as it is today to the families of those who choose to leave their own family's value system to embrace another that seems totally alien. That is what most religious conversions are made of.

This motif of discipleship as surrogate family must have been explicit to a certain degree during the life of Jesus. There is no reason, given the background just described, why it could not have been. Societal opposition must have been more widespread than Jesus' own family. Those in every family affected who were not impressed by this particular Galilean wonder worker must have rebelled. One accusation against Jesus, therefore, may well have been the subversion of 'family values'.

The same pattern continued in the Christian community beyond the life of Jesus. Some became disciples in family groupings, as did for instance the household of Stephanas at Corinth (1 Cor 1:16), of Cornelius at Caesarea (Acts 10:24,44-48), or of Lydia and the anonymous jailer at Philippi (Acts 16:15,33). Others, however, made individual decisions distinct from and sometimes against the wishes of authoritative members of their family, such as parents or older siblings.

In spite of the collectivist nature of ancient society, individual conversions to Judaism and private religions were common by the first century, and it is clear that the 
same thing was happening already in the first generation among Christians. One Corinthians 7:12-16 discusses what a believer should do if there is trouble in the marriage because of his or her change of allegiance. 1 Peter 3:1-6 shows that wives could be believers without their husbands, whom they might convert by their reverent and chaste behavior. About a century and a half later, Tertullian in Carthage (To his Wife 4,6 ) writes to convince the Christian woman to marry a Christian man, and describes all the daily difficulties she will encounter in her marriage if she does not. In spite of a strong literary tradition of marital subservience on the part of women, the Christian women of Tertullian's Carthage still made their own decisions about their faith. Slaves too could be admitted as believers without their owners. 1 Peter 2:18-25 suggests this, for slaves are made paradigms of the suffering Christ when they suffer unjustly at the hands of cruel owners. It is unlikely that Christian owners are envisaged here. A later text is more explicit. Hippolytus of Rome (Apostolic Tradition 15) in the early third century legislates that a slave who wishes to be baptized must have the endorsement of his or her owner if the owner is Christian; if not, the slave must be taught to please the owner in order to avoid scandal.

The church as God's household and family reappears in the later New Testament, especially in the Pastoral Epistles. Most explicit is 1 Timothy 3:4-5, where a bishop

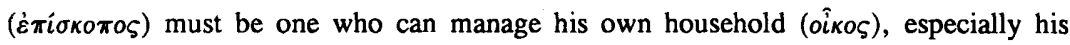
children. (This would include adult children, even those not living in the same house.) If he is not able to do this, he cannot hope to manage the church (see also $1 \mathrm{Tm}$ 3:15: 'the household [oikos] of God, which is the church of the living God'). The church became the substitute for the family, ascribing to itself all the claims to loyalty and dedication that the traditional family imposed on its members, but at the same time taking upon itself the obligation to provide for each member all the kinds of support that anyone had a right to expect from family.

In some cases, the choice of Christianity against one's family cost a life. In the martyrdom account of Perpetua and Felicitas, Perpetua, a young mátron of a distinguished family of Carthage, must withstand her father's anger and noncomprehension of the fact that she refuses to give up this new faith and so goes to her death. The Christian community as surrogate family was highly relevant in such circumstances, and in fact, occurs frequently in the martyr literature ${ }^{6}$. Jesus' sayings on the necessity of leaving house and family, of preferring him over everything and everyone else, must have been courage and comfort for those who found that their choice of faith in him brought them to the point of having to do just that.

It happened that families were broken up as a result of the choice for Christian faith. Already that possibility is posed by Paul in 1 Corinthians 7:12-16, though Paul 
lobbies for retention of the marriage bond if at all possible, on the grounds that the presence of the believer in the marriage makes it and the children holy, and may even convert the unbelieving spouse, the same hope expressed later by 1 Peter 3:1-2.

Not only marital unions, but blood ties were also sundered by acceptance of the faith. The words attributed to Jesus in the Q passage (Matthew) 10:34-36 (par Lk 12:51-53) can only mean this. Seven hundred years earlier, the prophet Micah had mourned the breakdown of family cohesion under outside pressure, and especially the breakdown of respect for elders, so that the enemy was present even in the household among closest kin - a terrifying experience that was often repeated in times of political repression. Listen to his words:

Put no trust in a friend, have no confidence in a loved one; guard the doors of your mouth from her who lies in your embrace; for the son treats the father with contempt, the daughter rises up against her mother, the daughter-in-law against her mother-in-law; your enemies are members of your own household.

(Micah 7:5-6 NRSV)

In the Gospel passage in point, Jesus takes up the same three parental relationships and declares that part of his mission is to pit these family members against each other: 'Do not think that I have come to bring peace, but the sword' (Matthew) or '... division' (Luke). Luke goes on even to reverse the direction of antipathy, attributing it not only to the inferior but also to the superior member of the dyad: not only son against father, but father against son; not only daughter against mother, but mother against daughter; not only bride against mother-in-law, but mother-in-law against bride. It is interesting that both Micah and Jesus pick relationships that were already troubled with rivalry; nothing is said about separating mother and son or sister and brother, the traditionally closest family relationships?.

It would seem, then, that much of what appears to be anti-family rhetoric from Jesus is in fact ex post facto reflection on what adherence to the faith was actually causing. That Jesus could be depicted as foreseeing it would have been very comforting: what is happening to us, they would think, has been happening all along to those who follow his call. Thus we have another case among so many in which an image of Jesus is constructed or at least augmented on the basis of contemporary questions and needs. 
To conclude: while Jesus is depicted in the Gospels as acting with compassion and understanding toward the families of those in need, he demonstrates an ambiguous attitude toward his own family, and many sayings are attributed to him that seem to encourage the breakdown of kinship and family structures. Thus from one perspective, Jesus could be called anti-family. Though not everyone would agree, I believe there is a basis of historical fact in this portrait. Jesus and his family for the most part did not get on well together once he began his public ministry. On the whole neither his family nor his fellow villagers from Nazareth ever became disciples.

Both Jesus and the developers of the early tradition lived, however, in a context of philosophical and apocalyptic movements that encouraged just the sort of separation from family and transfer of loyalty that Jesus demanded. Thus the early church nourished and augmented these sayings in order to foster the cohesion of church members with each other and their leaders, and to console those who found themselves in fragmented familial situations because of their faith. What this did to actual Christian families is not known. It may have strengthened them within the context of the larger church community; it may also have weakened family ties and structures of domestic authority. There is, however, no measurable effect of Christianity toward the weakening of the patriarchal structure of the Roman family.

From this perspective it is understandable that the early church, and thus the image of Jesus, was a threat to established society, along with such other radicals as Essenes and Cynics. One aspect of the church's tradition advocated the overthrow of the entire social system. That is probably why another strand of its rhetoric tried so hard in such documents as Ephesians, Colossians, the Pastoral Epistles, and 1 Peter to project an image of a law-abiding group that honored traditional family values and was no threat to political power.

Did Jesus uphold or undermine 'cultural values' with regard to family life? It depends on which, or whose, aspect of 'culture' we are talking about.

* This article was published in Du Toit, C W (ed), Images of Jesus, 122-140. Pretoria: University of South Africa. HTS is granted permission to reprint this article.

\section{Endnotes}

1 Professor Carolyn Osiek visited during August-September 1997 the University of Pretoria as CSD research fellow of Professor Andries van Aarde.

2 The History of Joseph the Carpenter, probably originally a Greek document from Egypt about $400 \mathrm{CE}$, details the life and death of Joseph, who was at the time of his marriage to Mary a widower of 89 years; he lived to the age of 111! (cf Schneemelcher 1991:484-85). 
3 Whether the 'brothers' are siblings or other relatives is not relevant here. I have seen countless examples in the Middle East today in which the word is used very loosely for any degree of relationship, and even for men from the same village.

4 Matthew 12:46-50; Luke 8:19-21; Gospel of Thomas 99; Gospel of the Ebionites in Epiphanius, Panarion 30.14.5. Luke softens the rebuke. Commentators demonstrate an understandable reluctance to attribute historicity to this passage, but then one must ask how it served the early community to compose the story. On the contrary, in later tradition, the family of Jesus become believers; cf Koester, 1980:200; Mack 1988:91 n 11).

5 Roman antiquities $(3.13 .4 ; 3.15 .2-5 ; 3.18-20 ; 3.21 .6)$. For Jewish sources, see also Joseph and Aseneth (11.4-6). Diogenes Laertius, Lives of the Philosophers, contains many comparable call stories in which families are left (esp 2.7; 2.48; 7.2-3). For other examples from Philo, Josephus, Qumran, Cynics, and Stoics, see Barton (1994:23-56).

6 For instance, Martyrdom of Perpetua and Felicitas (3, 15); Martyrdom of Montanus and Lucius (10-11, 18, 23); also Cyprian On the Unity of the Church $(6,23)$.

7 Milavec (1925:131-43) even suggests family intergenerational conflict as the setting for Matthew (5:39-48); Luke (6:27-38). Cf Didache (1.3-4), on nonresistence to oppressors and love of enemy.

\section{Works Consulted}

Barton, S C 1994. Discipleship and family ties in Mark and Matthew. Cambridge: Cambridge University. (SNTSMS 80.)

Corbo, V 1969. The house of St. Peter at Capharnaum. Jerusalem: Franciscan Printing Press. (Publications of the Studium Biblicum Fansciscanum.)

Koester, H 1982. Introduction to the New Testament, vol 2: History of early Christianity. Philadelphia: Fortress. (Hermeneia.)

Mack, B L 1988. A myth of innocence: Mark and Christian origins. Philadelphia: Fortress.

Milavec, A 1925 . The social setting of 'turning the other cheek' and 'loving one's enemies' in light of the Didache. BTB, 131-43.

Saller, R P 1984. Familia, Domus, and the Roman conception of the family. Phoenix 38, 336-355.

- 1994. Patriarchy, property, and death in the Roman Family. Cambridge: Cambridge University Press. (Cambridge Studies in Population Economy, and Society in Past Time 25.

Schneemelcher, W (ed), New Testament Apocrypha, vol 1, 484-85, tr by R McL Wilson. Cambridge/Louisville, Kentucky: Clarke/Westminster John Knox. 
Tzaferis, V 1983. New archaelogical evidence on ancient Capernaum. Biblical Archaeologist 46, 198-204. 